\title{
The Impact of Austerity Measures on Social Security Beneficiaries: The Case of Greece
}

\author{
Savvoula I. Mouratidou ${ }^{1}$ \\ ${ }^{1}$ Faculty of Social Administration and Political Science, Democritus University of Thrace, Greece \\ Correspondence: Savvoula I. Mouratidou, Faculty of Social Administration and Political Science, Democritus \\ University of Thrace, Komotini, 69100, Greece. Tel: 30-6977-714-028.
}

Received: December, 29, 2018; Accepted: January, 14, 2019; Published: February 21, 2019

\begin{abstract}
This article discusses how welfare cuts in Greece affected social insurance beneficiaries' access to better living conditions by raising the question why welfare benefits are not excluded from cuts even though they obviously minimize poverty rates in people of the third and fourth age. It focuses on the Memoranda reform measures imposed after 2010 acknowledging on the one hand that these measures are for the most part unjustifiable and in parallel locating which changes have been accepted and welcomed by the social insurance fund executives.
\end{abstract}

Keywords: impoverishment, austerity reforms, social benefits shrinkage, crisis

\section{Introduction}

Greece, being the weak link in the EU, unable to cope with the economic crisis (2007-2008), from 2010 and onwards was entered under the supervision of the Troika (I.M.F., E.S.M., E.F.S.F.). The international markets would not loan the country due to the general instability of its budgets and its inability to manage the situation. The Greek government borrowed on worse terms than countries facing similar problems since there was no interest in Greek bonds and the Europeans did not trust the ruling political parties that were in power (Kallitsis, 2014). In 2017, the Greek debt reached $178.6 \%$ of GDP (http://appsso.eurostat.ec.europa.eu). A decade after the crisis along with the subsequent imposition of austerity policies, Greek society is in deadlock (Petmesidou, 2011, 2012, 2013, 2014). The economy still risks bankruptcy and the government has difficulties in finding solutions for the poor (Featherstone, 2011, Louzis et al., 2011). The new liberalism measures (Jessop 2016) that government officials impose, as per the lenders' requests, are leading more citizens to impoverishment.

The economic crisis, as well as other overarching issues, such as rising unemployment, aging of the population, increase in life expectancy, the government deficit and the public debt, the decrease in jobs and the Greek government bonds devalued by $50 \%$, resulted in the welfare state's inability to cope with these problems mainly due to the unfavorable economic conditions. The method of austerity chosen for the reduction of deficits in the welfare state has also destabilized it. On the other hand, an increasing proportion of the population is led to poverty and social cohesion and solidarity decompose, turning the welfare state into a charity state (Robolis, 2013).

In particular, currently, one out of three households is unable to meet basic needs, such as heating, maintenance and health costs. Also, a significant number of middle-class citizens, especially the elderly over 75 , are unable to cover health care costs because it is "too expensive". This fact shows that the middle class is gradually led towards poverty becoming the "young poor" group of Greek society. Wage and pension cuts, increased household taxes, and health and education cuts led people to extreme poverty (Petmesidou, 2013a).

Following the outbreak of the economic downturn, the social budget was included in the state budget with serious consequences. The European Union requires the implementation of economically viable retirement schemes. Therefore, especially in Southern European countries, either pensions were reduced or retirement age limits were raised, or both were applied without a second thought. However, the problem does not lie in the abovementioned factors. More severe issues concern growth, employment rate and income distribution. The continuous measures that shrink the welfare state will certainly not improve the situation (Robolis, 2013). Dissatisfaction, especially in Southern European countries has been expressed by spontaneous mass civil protests, particularly in Greece outside the Parliament, through movements such as "the indignant", "the ties", "the farmers", and others, in Spain through the "Indignados" and recently in France through the "yellow vests" movement. 
Undoubtedly, one might argue that since pensions in Greece hold the largest share in social transfers and demonstrably reduce poverty (Dafermos and Papatheodorou, 2013, Petmesidou and Guillen, 2014; Venieris, 2013), they should be excluded from cuts. However, not all pensioners have enjoyed equal treatment since some have received multiple or extravagant pensions that did not correspond to the contributions paid in their working lives.

This article investigates the fact that the majority of Social Insurance Fund of Employees (IKA) pensioners, who receive minimum pension, are at large driven below poverty level even when the slightest decreases in their incomes occur due to the post-2010 austerity measures. Milder reductions in this group would be a little more costly but they would also have a positive impact on pensioners' protection from poverty. The reason why this research focuses on Social Insurance Fund of Employees IKA is because of its very large size (917, 956 pensioners). In comparison, the Fund of Farmers (OGA) has 641, 316 pensioners, the Fund of Civil Servants (GLK) 478, 245 and the Fund of Freelancers (OAEE) 366,583 (http://www.idika.gr/eseps-mhniaies-ek8eseis, December 2016).

\section{Social Security Reforms after the 1990s}

The sustainability of the insurance funds in Greece had been disputed since the early 1990s. The need for social security reform had always been obvious. However, it is quite typical for Greece, as Tinios (2005) claims, what type of reform is preferred. Reform efforts do not change past failures in depth. The insurance system is often criticized as costly on the one hand and economically and socially ineffective on the other. Petmesidou (1991, 2006) suggests that there is a low degree of social pressure for reforms. Trade unions cooperate with the state and do not allow the development and implementation of social policy on a systematic and stable basis.

In the early 1990s, reforms in the insurance sector aimed at reducing public debt and social security deficits by increasing retirement ages, working days and contributions (1902/1990, 1976/91, 2084/92), (Hadjidimitriou \& Psilou, 1993; Petmesidou, 1996, 2006). Later, some reform efforts were made, such as the merger of insurance funds facing viability issues with larger, healthier funds (Law 2676/1999). However, those changes were not significant enough (Petmesidou 2006, Featherstone and Tinios 2006). The reform effort continued in 2002 (Law $3029 / 2002$ ), but was still characterized as inadequate in relation to the sustainability problem of the insurance system. The most significant attempt to reduce fragmentation occurred with the introduction of Law 3655/2008. Individual funds were included in the Social Insurance Fund of Employees (IKA) with the ultimate aim of achieving homogeneity (Petmesidou 2010). The past reform efforts were not successful and the reasons for failure, according to Featherstone and Tinios (2006), are summarized in the low level of governance efficiency, fragmentation, lack of consensus between social partners and a legacy of conflict.

After 2009, the economic crisis left no room for experiments. Three Memoranda (support programs for the Greek economy) were voted between 2010 and 2015 . The repercussions for social security beneficiaries, especially those receiving minimum pension, are not affordable. Nektarios (2008) suggests that the majority of Greek pensioners receives minimum pension ( $€ 486.84$ for IKA pensioners, $€ 406.00$ for OAEE pensioners and $€ 360.00$ for OGA pensioners). All laws voted in that period were introduced in the Parliament as urgent (that meant there was not enough time given for deliberation) suggesting that they would contribute to the financial consolidation of insurance funds. The reforms implemented aimed primarily at limiting and repealing social benefits and secondly at making structural changes.

The first program voted on 3rd May 2010 is known as "The Economic Adjustment Program for Greece". It included structural changes such as the establishment of the Disability Certification Center (KE.P.A.) and the introduction of a measure to separate health from pension by establishing a single health provider (National Organisation for the Provision of Health Services, E.O.P.Y.Y.) that was to by launched in January 2012 (Petmesidou, 2011, 2012). The institutional changes also contained the imposition of an additional special solidarity contribution by pensioners (Law 3863). However, it concerned only those who received pensions exceeding $€ 1,400$ per month. According to Law 3845/2010 Christmas, Easter and Holiday Leave Benefits were reduced.

The second Memorandum, voted in June 2011 is referred to as "Urgent Arrangements to Negotiate and Conclude an Agreement with the European Support Mechanism". This program also included structural changes and institutional shrinkages. With the adoption of Law 4093/2012, regulations were introduced that concerned raising the retirement age and pension cuts starting from 1st January 2012 and the repeal of Christmas, Easter and Holiday Leave Benefits, starting from 1 January 2013. Law 4024/2011 reduced pensions of up to $€ 1,000$ for pensioners older than 55 by $20 \%$ and for pensioners younger than 55 by $40 \%$. Law 4051/2012 impacted main pensions of up to $€ 1,300$.

In same period, the Unified Fund of Supplementary Insurance was created and the consolidation of most auxiliary funds was achieved (Law 4052/2012). Moreover, with the adoption of that Law, the calculation method for 
supplementary pensions changed as well. Up until 1st January 2015, the total contributions paid by the insured individuals during their working lives would be taken into account (Petmesidou 2013b). The data have shown that the shrinkages rose to $50 \%$.

On 13th August 2015 the third Memorandum was voted for by the majority of the Greek Parliament. As a result, Law 4336/2015 passed. This Law leaves room for those who reach the retirement age limit until 2022. After that the age limit is assimilated for all at the age of 67. These changes have not affected disability retirements. In addition, incentives to stay at work were provided through a $10 \%$ (monthly) reduction to the already reduced pension for those who retire earlier. Minimum pension (€486.84) will be granted to those who retire at the age of 67 years. Law 4334/2015 imposes a deduction of $6 \%$ for health insurance on auxiliary pension and an increase from $4 \%$ to $6 \%$ on the main pensions.

The commitments of the third Memorandum, however, still required the enactment of Law 4387/2016 on the establishment of the Unified Social Insurance Institution (EFKA). It also changed the pension system from "pay as you go" to a "funded" pension scheme based on individual accounts from 2002 onwards. However, the earnings of prospective pensioners have been shrinking since after the onset of the crisis. This means that in the future the pensions will be very low. This Law also sets the gradual abolition of the Social Solidarity Pension Allowance (EKAS) and repeals it in full from those who retired after its enactment. EKAS was granted to support pensioners with low income (Law 2434/1996). The abolition of this allowance is expected to have negative impact on those pensioners. This Law also includes harsh limitations on survivors' pensions. National pension amounts to $€ 384.00$ but it is reduced proportionately for those who have not completed 20 years of insurance throughout their working lives or for those residing in Greece for less than forty years. The implementation of this Law is a severe step backwards which inhibits people from being optimistic about the future of social security in Greece.

However, Tinios (2010) suggests that although the country still needs to deal with the effects of the latest economic downturn, the interventions of the post-crisis governments do not differ from those of the past. In particular, social dialogue is not promoted, and when it takes place, it is always in the form of an urgent procedure, which leaves little room for making ways. In addition, there is no discussion on the adequacy of the insurance system applied, based on quantitative and actuarial studies, except for those conducted by the General Confederation of Employees in Greece (GSEE) which is, however, only a player that participates in bargaining as a social partner. Consequently, "... any attempt is doomed even before it even begins". Of course, social policy focuses on pensions policies, highlighting the aging of the population as the most important cause of social welfare deficits and, in general, there is a tendency that shifts responsibility towards citizens themselves (Robolis 2013).

\section{Methodology}

This study uses two questionnaires as primary data collection tools. The first is addressed to beneficiaries of the Insurance Fund of Employees (IKA) and the second to its executives who have a lot of working experience in the social security sector. The sampling method adopted is that of simple random sampling. In order to achieve representativeness, the branches of Insurance Fund of Employees (IKA), where the questionnaires were distributed, were selected randomly (by draw). These questionnaires are structured with closed-type questions in the form of dichotomous answers, simple or multiple-choice scales, and Likert scales (five-level) that determine the degree of agreement between the respondent and his or her point of view. The resulting data is processed using the SPSS 17.0 statistical program (Frequencies). The results reported below are derived from an opinion survey conducted on a sample of pensioners from the Insurance Fund of Employees (IKA). The beneficiaries who participated in the survey were 403 and the main questions posed are: How do reductions impact on the beneficiaries' future expectations and hopes? How strong is their distrust before the inability of state institutions to manage pensioners' interests? Is the state able enough to maintain a decent standard of living for the beneficiaries after implementing cuts and austerity policies? Is minimum pension really excluded from reductions as the government claims? The Institute's executives were 109 and they were asked whether they find the measures of structural or institutional changes justifiable and whether they lead to the rationalization of the social security system on the one hand and whether pensioners with low income should be excluded of reductions on the other.

Research constraints mainly concern the time period of the survey, which is closely related to political, economic and social developments in Greece that cause a great deal of uncertainty and confusion among citizens. The willingness of individuals to contribute to the survey is pertinent to the general discomfort they feel as a result of the current economic crisis which finds Insurance Fund of Employees (IKA) beneficiaries hostile against institutions and the state. This anger affects some of them in a positive way by strengthening their will to express themselves, even by completing a questionnaire. However others refuse to do so and avoid any communication or simply mistrust this effort. They are all mainly concerned about unemployment, income and property taxes, 
pension cuts, decrease of their savings and unemployed family members (Matsaganis 2011, Matsaganis and Leventi 2014).

Of course, the Insurance Fund of Employees (IKA) executives' concerns have different dimensions. In their case, there is a predominantly disconcerting disincentive for wage restraint and an increase in workload (Matsaganis 2013). While answering the questionnaire, they often expressed their fears of forthcoming redundancies since that had already happened to their colleagues. This concern is particularly stressed by executives with lower educational level. In fact, these two factors inhibit some of them from completing the questionnaire consolidating a more general perception that research has no effect, and that results will not be taken into account as stated by the beneficiaries.

\section{How have post-2010 Austerity Measures Impacted Insurance Fund of Employees (IKA) Pensioners?}

This part of the study aims to capture the extent of the effect of income decline upon the ability of pensioners to meet basic needs. It is noteworthy that at the beginning of the crisis in Greece (2009), the Housing Cost Overburden Rate amounted to $21.8 \%$ and in 2016 to $40.5 \%$. (Source: http://ec.europa.eu/eurostat/data/database). Thus, an image on the purchasing power of social welfare beneficiaries has been formed after the onset of the last recession. From the results it is presumed that a significant proportion of beneficiaries $(46.5 \%)$ faces difficulties in meeting basic needs regarding nutrition and that is mainly because those beneficiaries also support unemployed family members (Chart 1).

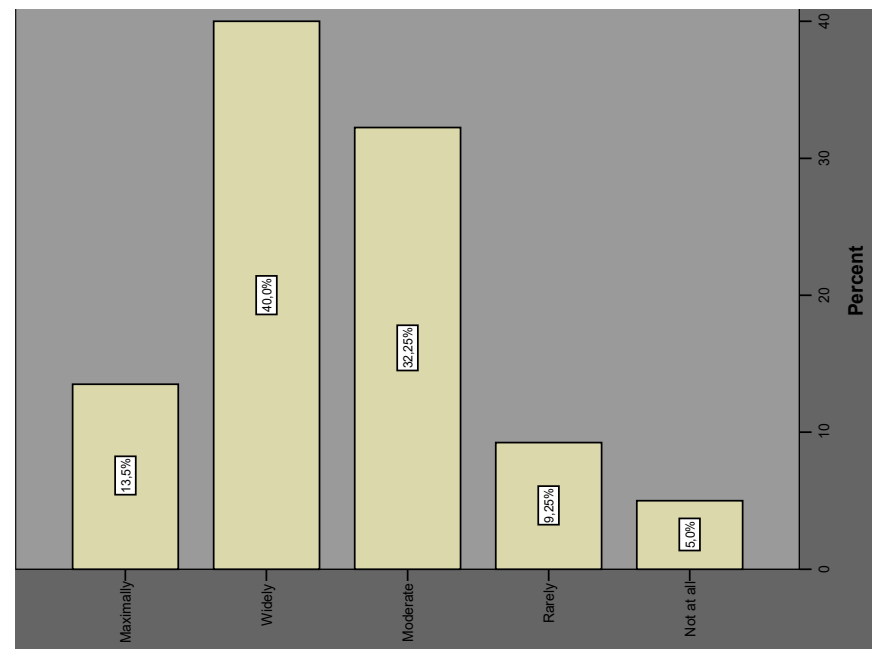

Chart 1 . Have you been able to meet basic nutrition needs since after 2010 ?

Furthermore, as to basic clothing and footwear needs, the results confirm that only a minimal percentage is able to meet them (6.8\%). Priority is primarily given to meeting food needs first and then other basic needs (Chart 2).

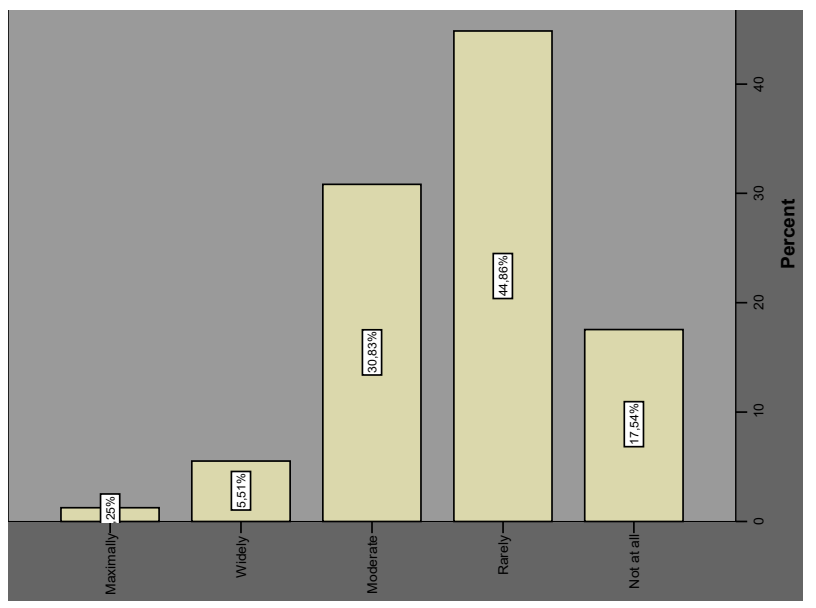

Chart 2. Have you been able to meet basic clothing and footwear needs since after 2010?

The situation seems less encouraging when it comes to medication coverage or medical costs. Beneficiaries of social allowances face difficulties (6.6\%) related to medical costs or medication coverage in general. According 
to Eurostat the Self -Reported Unmet Need for Medical Care rate in 2009 was nearly 5.5\% and in 2015 it raised to $12.3 \%$. (Source: http://ec.europa.eu/eurostat/data/database). In disability situations, when people wish to have access to better and immediate treatment (e.g. by avoiding waiting lists), they are often directed to private practitioners and hospitals where they have to pay large sums of money. Due to lack of government funding, from 2010 onwards, healthcare conditions have deteriorated significantly and, as a result, citizens are at risk, not from diseases but from hospital-acquired infections (Fountoulakis et al. 2012, Kentikelenis et al. 2011). A large percentage of respondents stated further that they may not cover private health expenditure. Once more, this makes one wonder about the role of the state in respective cases and its inability to support citizens when they are in need. However, this could be refuted arguing that social practice (most of the times with few specialties) and social pharmacies have assumed the responsibility to support the financially weak people in similar situations (Sotiropoulos and Bourikos 2014, Giannitsis and Zografakis 2015). Undoubtedly, solidarity is invaluable and demonstrates a high level of social capital and cohesion in a society (Jenson 1998, Forrest and Kearns 2001). On the other hand, for many people, the resort of citizens to such structures raises issues of dignity. Some of them think of themselves as stigmatized. There are also a few who claim that although they have paid social insurance contributions during their working lives, now, at an age in which they are unable to work the state is unable to cover the costs for their medical care. Moreover, there are examples of people who postpone visits to healthcare facilities because they are uninsured. This occurs mainly among former freelancers or employees in the private sector who, due to the latest recession, either lost their jobs or went bankrupt (Fountoulakis et al. 2012). This postponement might mean further worsening of their health. Therefore, discontent is particularly strong and makes the citizens' feeling of uncertainty of what is to follow even stronger (Chart 3).

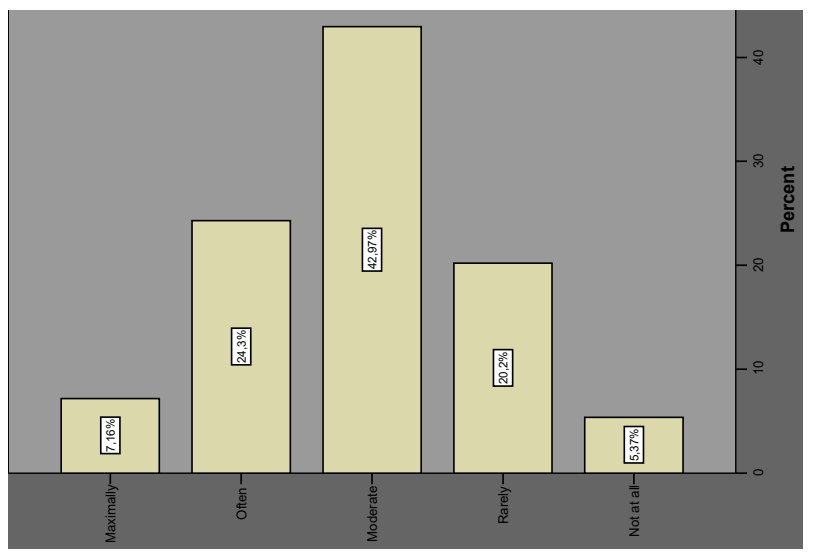

Chart 3. Have you been able to afford medication coverage or medical costs in general since after 2010 ?

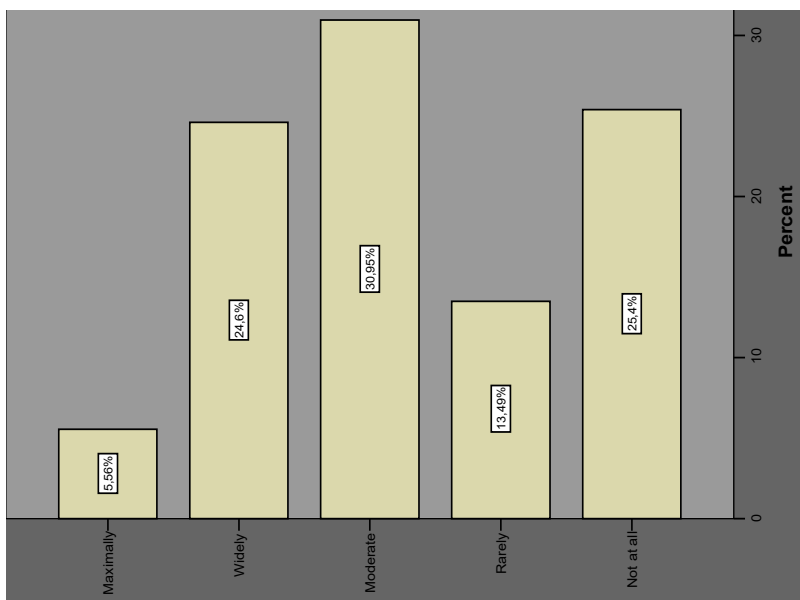

Chart 4. Have you been able to afford costs related to house loans since after 2010 ?

In addition, several households from 2010 onwards find it difficult to pay house loans because of cross-cutting reductions in salaries and pensions (Louzis et al. 2011, Matsaganis 2013). A significant proportion (25.4\%), therefore, is not able to cover such costs. There also exists the risk of the loss of one of the most important human 
goods: housing. In Greece, there has already been an increase in homelessness, especially in large urban centers (Theodorikakou et al. 2013, Mavridis and Mouratidou 2018). On the other hand, political parties of the opposition take advantage of the state's failure to meet such needs with a view to gain votes and climb to power (such as the "I'm not paying" movement) (Chart 4).

The above question also concerns monthly utility costs that include communal taxes, water and heating. Such costs have been characterized by many households as unbearable (Matsaganis 2013, Papadopoulos and Roumpakis 2012, 2013). The majority (55.6\%) mentions difficulties in covering utility costs. More particularly, the decline in household incomes implies inability to respond to heating costs. In 2014, the share of households that could not afford to keep its dwelling warm was 52\%. (Source: http://ec.europa.eu/eurostat/data/database). This results, on the one hand, in poor health due to low temperatures or inhalation of carbon monoxide (the use of braziers has caused even deaths) and, on the other hand, in the smog increase because of the use of inappropriate heating materials. It is obvious that if beneficiaries with a monthly income have expressed such weakness, people who are unemployed or have precarious jobs with meager payment and most often without insurance coverage are far worse (Chart 5).

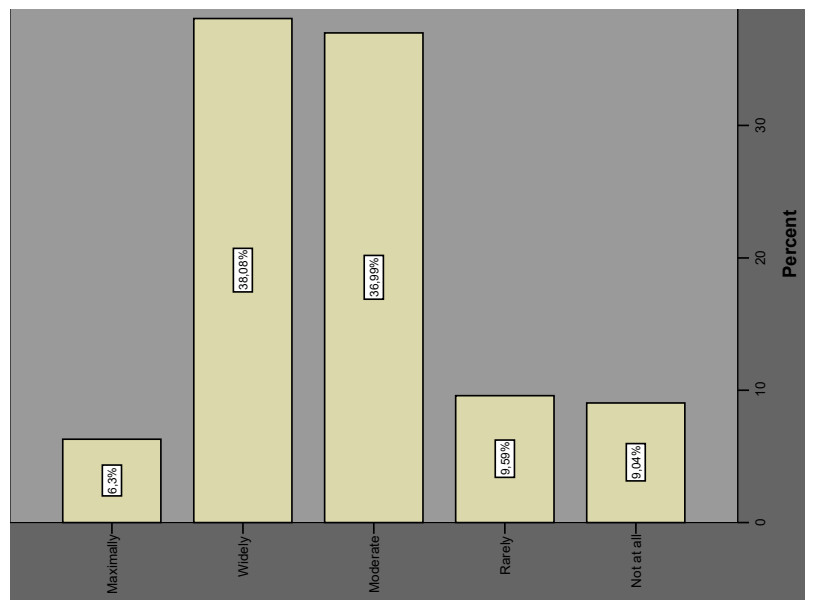

Chart 5. Have you been able to cover utility costs such as communal taxes, water supply and heating since after $2010 ?$

Nonetheless, the economic exhaustion of social security beneficiaries is strongly established in their ability to meet needs related to entertainment (Fragos et al. 2012). The vast majority of pensioners (48.4\%) cannot meet basic needs related to entertainment. It could, of course, be argued that entertainment is not a basic human need. However this signals that society returns to past situations where the privilege of entertainment was only for prosperous social classes while those hailing from lower social strata were not entitled to such right. Thus, the inability of people nowadays to meet such needs shows a regression. Nevertheless, coverage of basic entertainment needs including those determining whether a citizen lives within poverty lines or not-, is a human need, not a luxury (for example, one week vacation per year or a visit to the theater) (Chart 6).

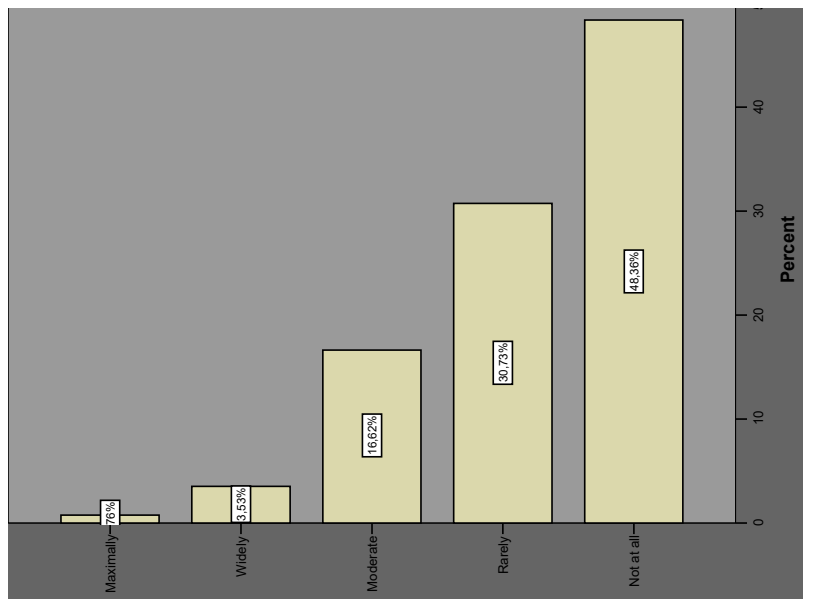

Chart 6. Have you been able to meet entertainment related needs since after 2010 ? 
The next question concerns the extent to which the recipients of social benefits cover costs related to the education of their children. The results of the research corroborate the alleged expanding exhaustion of the population from 2010 onwards. The majority of the beneficiaries (45\%) is unable to cover such costs. Steps backwards are recorded as to the ability of households to spend on the education of their members (Fragos et al. 2012, Papadopoulos and Roumpakis 2012, 2013). So, this privilege, once again, is only for those who can afford the costs for quality education services, as happened in the past. The state has again shown inadequate to cover basic needs of the population, such as education, because of reductions in social benefits. Also, the results of the analysis show that the amount of pension granted does not differentiate as to whether the beneficiaries face difficulties in meeting basic education needs of their family members (Chart 7).

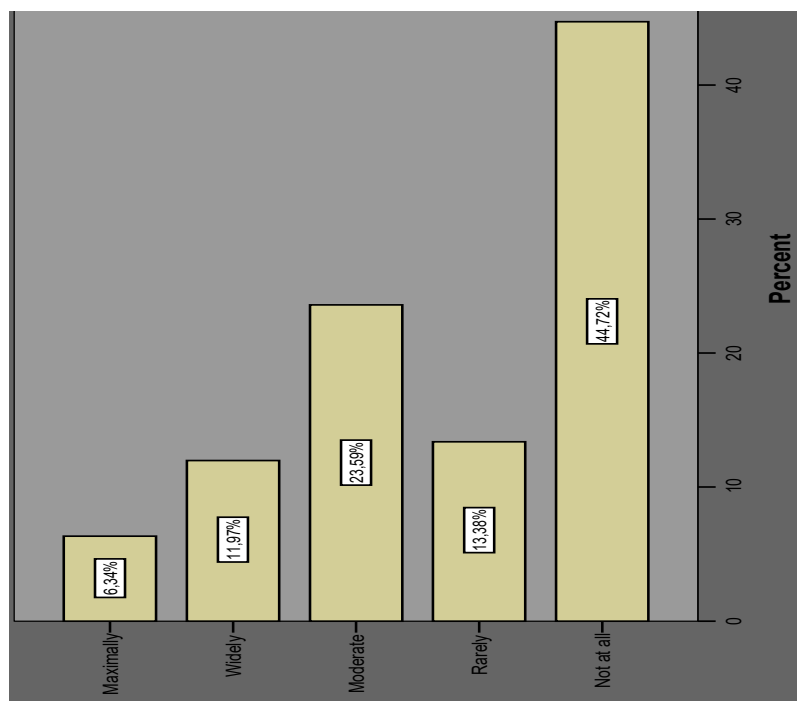

Chart 7. Have you been able to cover education related costs for family members since after 2010 ?

\section{The Opinion of Insurance Fund of Employees (IKA) Executives on the Post-2010 Measures that Affected the Social Security System}

The results shown below were extracted from the opinion survey of highly experienced Insurance Fund of Employees (IKA) executives. Unquestionably, the measure reducing main and supplementary pensions (Petmesidou 2010, 2011, 2012, 2013a, 2013b) is not seen by the executives as a legitimate change in the country's pension system. However, there are cases of healthy funds of which excessive benefits do not correspond to the contributions currently being paid. At the same time reductions for pensioners with more than one pension will lead to the rationalization of the system (Featherstone 2011, Petmesidou 2006). Given also the fact that the majority of beneficiaries of the Insurance Fund of Employees (IKA) receives minimum pension, through this policy of cuts, the social protection system will be affected resulting to the slippage of low-income pensioners to poverty level (Petmesidou 2013a, 2013b). Regarding the need for consolidation in the pension system through cuts in main and supplementary pensions, the majority of executives states that there is "none" $(46.3 \%)$, or there is "rarely" $(25 \%)$ a justified measure (Chart 8). 


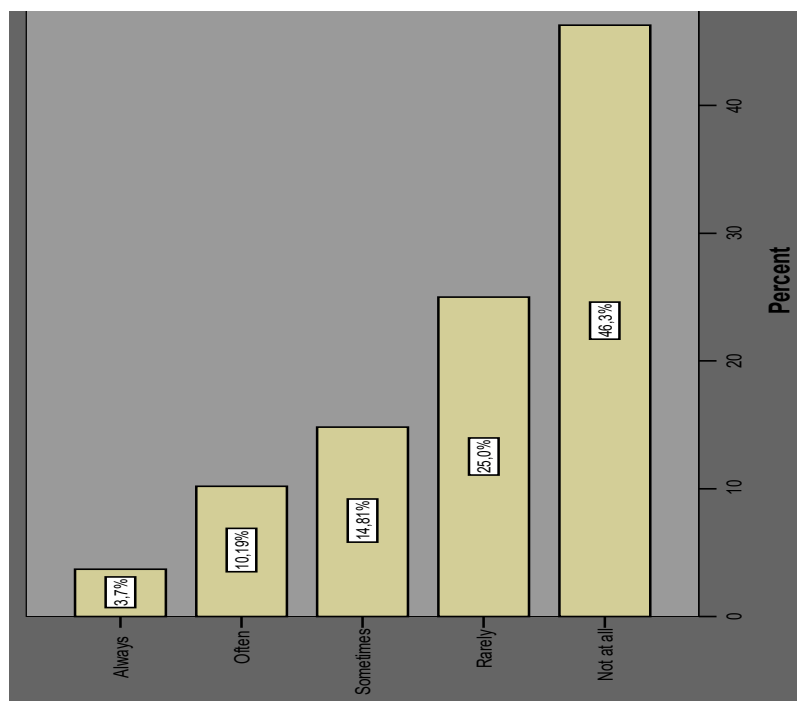

Chart 8 . Has the reductions of primary and auxiliary pensions been a decisive measure for the viability of the Social Security System after 2010?

Undoubtedly, the changes in the retirement age limit are imperative since funds do not have reserves capable of paying future pensions. Factors such as prolonged unemployment, increased life expectancy and declining birth rates constitute this measure necessary (Lyberaki and Tinios 2012). Moreover, rules which favor certain occupational groups, such as bank employees, who retire following a fifteen-year period of work, have negative effects on the ability of insurance funds to pay pensions. The results of the research show a controversy regarding the need of that measure. $30.84 \%$ of the executives suggests that increasing the retirement age limit is not a legitimate change. On the other hand, some of them, 28.04\%, claim that the retirement age limit should be necessarily increased (Chart 9).

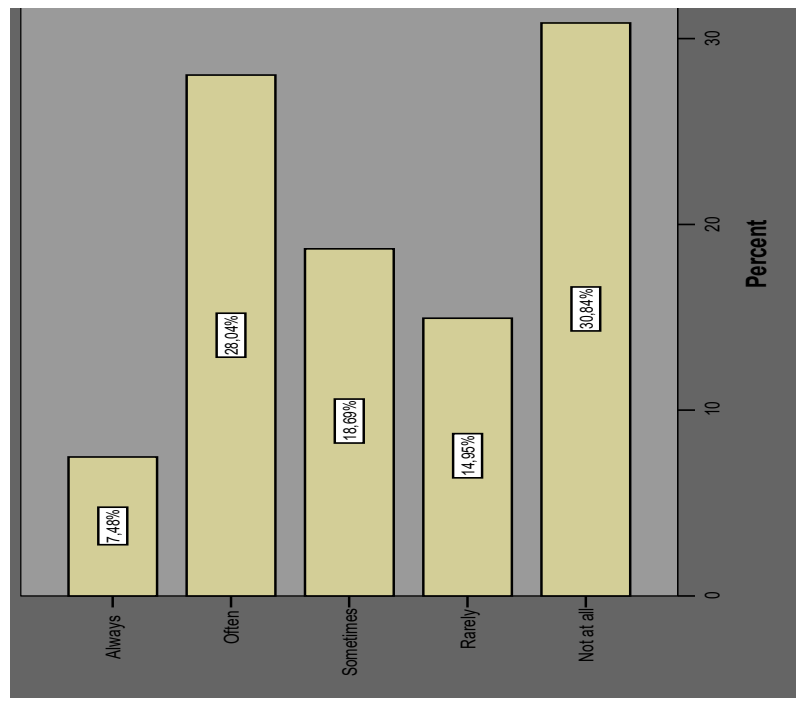

Chart 9. Has the increase of the retirement age limit been a significant measure for the viability of the Social Security System since after 2010?

Another measure imposed by the lenders and ratified by the Greek parliament, during the same period, is the reduction and, after 2013, the abolition of Christmas, Easter and holiday leave benefits. Directly related to the previous measure, it is obvious that the general reduction and cuts policies on pensions support the view that the cuts are imposed in a cross-cut manner, disregarding that $70 \%$ of pensioners in Greece receive minimum pension, as mentioned above. The attitude of the executives towards this measure is particularly critical. The vast majority characterizes this measure as "not at all" (61.68\%), and as "rarely" (24.3\%) justified (Chart 10). 


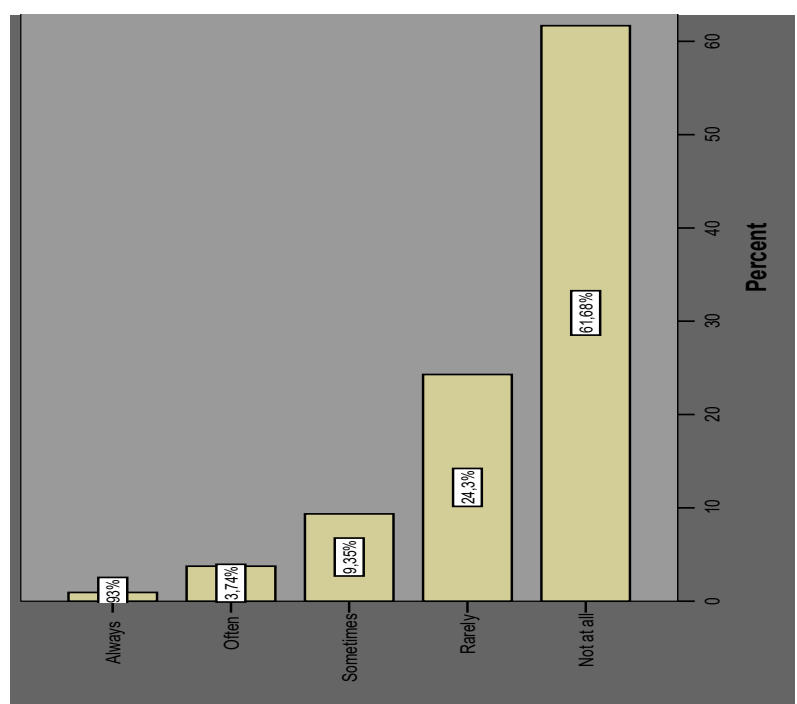

Chart 10. Has the reduction-abolition of Christmas, Easter and Holiday leave benefits been a necessary measure for the viability of the Social Security System since after 2010?

Additionally, the increased age limit for granting, reducing or abolishing pension for the uninsured elderly is another measure applied in order to improve, as argued by its initiators, the country's fiscal situation (Petmesidou 2012, 2013a, 2013b). However, it leads a large proportion of the elderly to poverty. Specifically, the implementation of this measure is designed to meet the needs of those elderly who have not met retirement conditions in any other social insurance fund, domestic or foreign. Although the benefit paid is low, it covers some of their basic needs. It could be argued that this 'allowance' policy, which does not significantly improve the financial situation of the elderly, somehow provides some minimal support. Nonetheless the reduction, abolition or the age limit increase for eligibility at the age of 67 concerning pensions for the uninsured elderly is contended by the majority (64.49\%) of the executives as "not" justifiable (Chart 11).

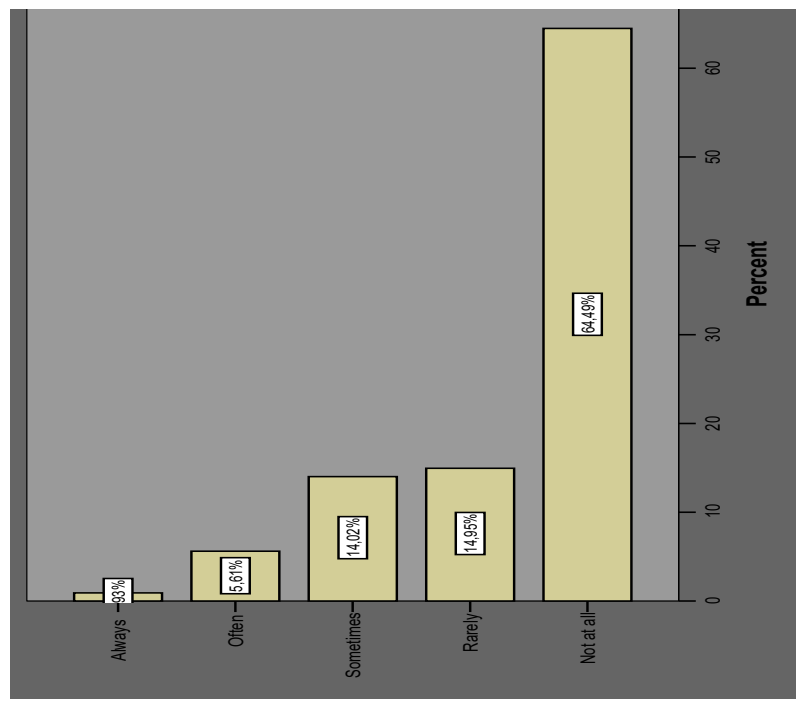

Chart 11. Has the increased age limit for pension eligibility, and the reduction or abolition of pension for the uninsured elderly been a justifiable measure for the viability of the Social Security System since after 2010?

What is more, benefits for families with three or more children and other categories of the population could not be left untouched by the sweeping changes introduced by the Memoranda, which dramatically dissolute the welfare state (Papadopoulos and Roumpakis 2012, 2013). Nonetheless, as mentioned above, all these measures lead to further impoverishment. However, objections are raised as to the criteria of the eligibility of several groups. According to a statement these privileges were used to attract votes or given to people who had no financial need and still receive benefits as no previous resource inspection had taken place. The administration should be able to 
make use of such inspections in order to provide benefits to those that demonstrably have low incomes. The survey results reflected the dissatisfaction of executives on the implementation of this measure. The removal of large family benefits is not accepted as justified by the majority (59.81\%) (Chart 12).

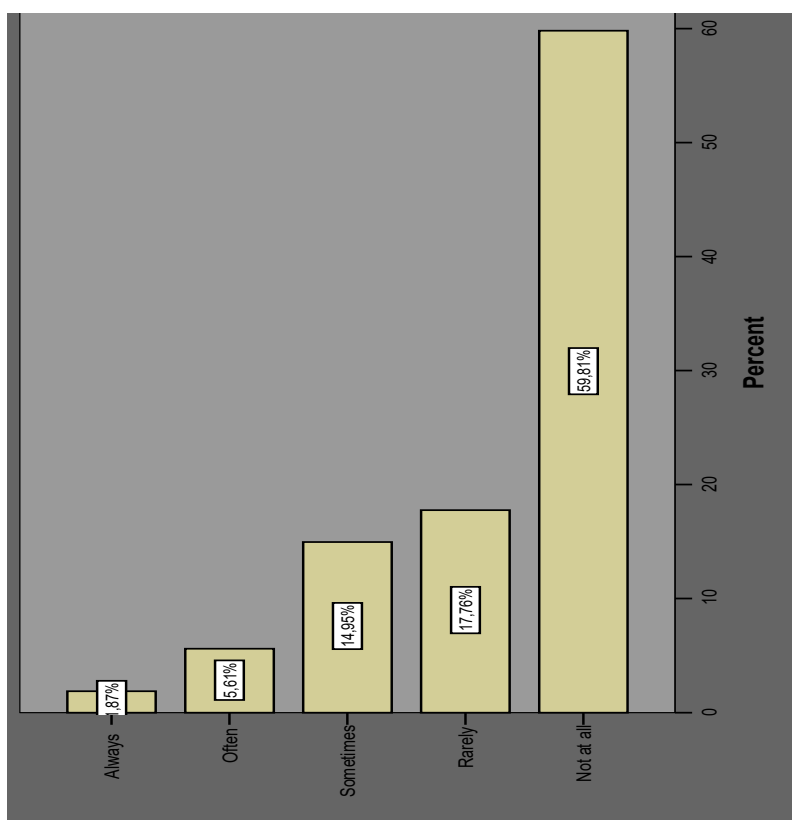

Chart 12. Has the reduction in benefits for families with three or more children been a necessary measure for the viability of the Social Security System since after 2010?

Furthermore, the establishment of the Disability Certification Center (KE.P.A.) is recognized as measure of rationalization and consolidation for disability benefits provided by the Insurance Fund for Employees (Petmesidou 2012). The establishment of KE.P.A. was deemed necessary due to the fact that the system according to which the percentage of disability was assessed by health committees, which operated until August 2011, was particularly vulnerable to political pressures and other pressure groups. Corruption in the form of bribery, favoritism and electioneering had taken enormous proportions. The political intervention of government officials, the local government and other organizations were downright common. Many are those who do not meet the disability rate based on medical criteria and, thus, lose the right to receive benefits and this means that they have no other state support. In the survey, the results suggest that the majority of the executives maintains that the structure of the Disability Certification Center is totally (42.45\%) and for the most part (33.02\%) an essential change. It is expected that the establishment of KE.P.A. will contribute significantly to the reduction of the misappropriation of social resources (Chart 13).

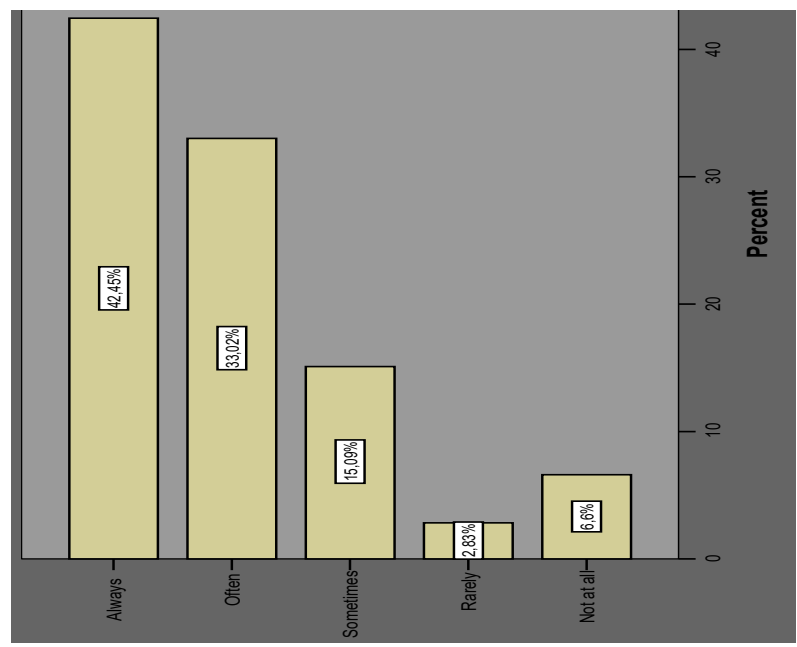

Chart 13. Has the establishment of the Disability Certification Center (KE.P.A.) been an imperative measure for the viability of the Social Security System since after 2010? 
Last but not least, the First Memorandum (2010) introduced a measure separating health from pension resulting in the creation of a single health provider to launch from January 2012 (Petmesidou 2011, 2012). Arguably, this measure will lead, in the long run, to beneficial effects with regard to spending. Of course, the cuts and the deterioration of quality of the services provided by the newly established body lead to a further decrease in living standards. What is more, in the long run, increase in morbidity and mortality will be expected if these costs do not contribute to the prevention and treatment with advanced methods. Although there are modest thoughts regarding the efficiency of the National Organization for the Provision of Health Services (EOPYY), the majority (60.95\%) of executives argues that this measure will significantly improve the rationalization of the health system while a $22.86 \%$ has a more moderate stance by selecting the answer somewhat (Chart 14).

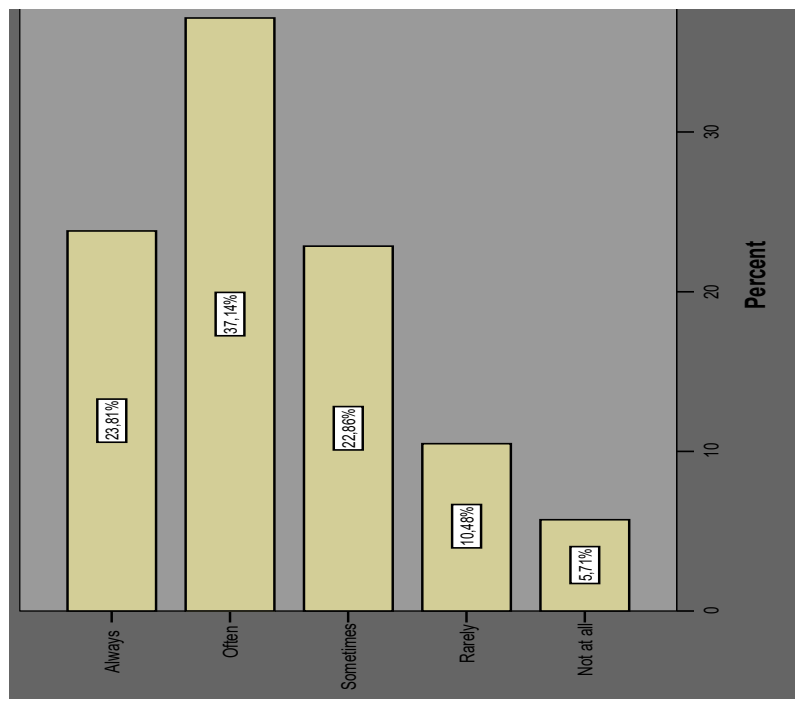

Chart 14. Has the creation of a Single Health Provider been an essential measure for the viability of the Social Security System since after 2010?

\section{Conclusion}

The experience of the implementation of the First, Second and Third Memorandum shows that pensions are the easy solution, since not only they are not exempted from cuts but any further change has been more burdensome than the previous one.

The findings of the survey show that the austerity measures implemented after 2010 have deteriorated the living standards of pensioners. However, the consequences of the Memoranda are more devastating for pensioners with low income. For example, the abolition of Christmas, Eastern and Holiday Leave Benefits has not the same impact on someone who receives a pension amount of $€ 1,300$ monthly as for someone who receives only $€ 486.84$ per month.

On the one hand, the measures have been imposed in a cross-cutting manner on the pensioners' income and, on the other hand, those pensioners have to face a dramatic increase in the cost of living with additional taxes. Therefore, most households are unable to cope with everyday needs. The discomfort of pensioners is reflected on the results of this research. They feel widespread discontent from income deductions, which, as mentioned above, affect them particularly by penalizing those who receive minimum pension. They gradually lose their ability to ensure medical care for themselves, which has now become their own responsibility, and education for their children, which has been largely privatized or is expected to be further privatized, to cover basic nutrition needs, clothing and footwear, as well as expenses related to housing. And all this occurs notwithstanding that it has been widely supported by academics that pensions demonstrably reduce poverty in Greece.

The survey findings also indicate that the measures concerning structural reforms are welcomed by most executives. However, they consider reductions in social benefits as unjustified, in particular those concerning citizens with low income. It is suggested that in times of austerity the pensioners and in general citizens with low income should be excluded from welfare cuts. The government should first implement reforms aiming at state reconstruction and then evaluate the outcomes of such reforms and, if needed, adopt measures leading to institutional changes. In any case though, low income pensioners should be protected from falling into poverty since they are unable to meet their basic needs otherwise. 


\section{References}

Chadjidimitriou, F., \& Psilou, G. (1993). New Social Security Law. Athens: Publications of Labor and Social Security Law (in Greek).

Dafermos, Y., \& Papatheodorou, C. (2013). What Drives Inequality and Poverty in EU? Exploring the Impact of Macroeconomic and Institutional Factors. International Review of Applied Economics, 27, 1-22.

Featherstone, K. (2011). The Greek Sovereign Debt Crisis and EMU: A Failing State in a Skewed Regime. JCMS, Vol. 49. https://doi.org/10.1111/j.1468-5965.2010.02139.x

Forrest, R., \& Kearns A. (2001). Social Cohesion, Social Capital and the Neighborhood. Urban Studies, 38, 21252143.

Fountoulakis, K., Grammatikopoulos, I., Koupidis, S., Siamouli, M., \& Theodorakis, P. (2012). Health and the financial crisis in Greece. The Lancet, 379, 1001-1002. Retrieved from $\mathrm{http}: / /$ www.thelancet.com/journals/lancet/article/PIIS0140-6736(12)60422-

X/fulltext?rss=yes\&utm_source=feedblitz\&utm_medium=FeedBlitzEmail\&utm_content=196607\&utm_ca mpaign $=0$

Fragos, Ch., Fragos, C., Sotiropoulos, I., Orfanos, V., Toudas, K., \& Gkika, E. (2012). The Effects of the Greek Economic Crisis on Eating Habits and Psychological Attitudes of Young People: A Sampel Survey among Greek University Students. WCE, 1, 485-489. Retrieved from http://www.iaeng.org/publication/WCE2012/WCE2012_pp485-489.pdf

Giannitsis, T., Zografakis, S. (2015). Greece: Solidarity and Adjustment in Time of Crisis. IMK Study Nr.38. Retrieved from https://www.econstor.eu/bitstream/10419/113255/1/820634719.pdf

Government Gazette 115 / Vol. A /15-07-2010. Law 3863. Retrieved from https://www.et.gr

Government Gazette 222 / Vol. A / 12-11-2012. Law 4093. Retrieved from https://www.et.gr

Government Gazette 226 / Vol. A /27-10-2011. Law 4024. Retrieved from https://www.et.gr

Government Gazette 40 / Vol. A /29-02-2012. Law 4051. Retrieved from https://www.et.gr

Government Gazette 65 / Vol. A /06-05-2010. Law 3845. Retrieved from https://www.et.gr

Government Gazette 80 / Vol. A / 16-07-2015. Law 4334. Retrieved from https://www.et.gr

Government Gazette 85 / Vol. A/12-05-2016. Law 4387. Retrieved from https://www.et.gr

Government Gazette 94 / Vol. A /14-08-2015. Law 4336. Retrieved from https://www.et.gr

Jenson, J. (1998). Mapping Social Cohesion: The State of Canadian Research. CPRN Study No F/03. Ottawa: Renouf Publishing Co. Ltd. Retrieved from http://www.cccg.umontreal.ca

Jessop, B. (2016). Neo-Liberalism, Finance-Dominated Accumulation, and Permanent Austerity: a Cultural Political Economy Perspective. Retrieved from https://www.researchgate.net/publication/312587424_NeoLiberalism_Finance-

Dominated_Accumulation_and_Permanent_Austerity_a_Cultural_Political_Economy_Perspective

Kallitsis, K. (10/19/2014). The International Crisis and its Impact on Markets. Newspaper Kathimerini (in Greek). Retrieved from http://www.kathimerini.gr

Kentikelenis, A., Karanicolos, M., Papanikolos, I., Basu, S., Mckee, M., Stucker, D. (2011). Health Effects of Financial Crisis: Omens of a Greek Tragedy. The Lancet, 378, 1457-1458. https://doi.org/10.1016/S01406736(11)61556-0

Louzis, D., Vouldis, A., \& Metaxas, V. (2011). Macroeconomic and Bank-Specific Determinants of NonPerforming Loans in Greece: a Comparative Study of Mortgage, Business and Consumer Loan Portfolios. Journal of Banking and Finance. https://doi.org/10.1016/j.jbankfin.2011.10.012.

Lyberaki, A., \& Tinios, P. (2012). Labour and pensions in the Greek crisis: The Microfoundation of disaster. Zeitschrft for Politik und Gesellschaft, 3, 363-386. Retrieved from https://s3.amazonaws.com/academia.edu.documents/32881797/Sud_Labour_and_pension_2012.pdf?AWSA ccessKeyId=AKIAIWOWYYGZ2Y53UL3A\&Expires $=1508059467 \&$ Signature $=$ F18\%2BbgOqCxOkolN2 wm35\%2F6MxBmE\%3D\&response-contentdisposition=inline \%3B\%20filename\%3DLabour_and_pensions_in_the_Greek_crisis.pdf

Matsaganis, M. (2011). The Welfare State and the Crisis. The Case of Greece. Journal of European Social Policy, 


\section{1. https://doi.org/10.1177/0958928711418858}

Matsaganis, M. (2013). The Greek crisis: Social impact and social responces. Friedrich Ebert Stiftung Study. Retrieved from https://library.fes.de/pdf-files/id/10314.pdf

Matsaganis, M., \& Leventi, C. (2014). The Distributional Impact of Austerity and the Recession in Southern Europe. Journal of South European Society and Politics, 19.

Mavridis, S., \& Mouratidou, S. (2018). The Phenomenon of Homelessness during the Greek Economic Crisis 2009-2018. Humanities and Social Science Research, 1(2). https://doi.org/10.30560/hssr.v1n2p23.

Nektarios, M. (2008). Social Security Reform with Consent and Transparency. Athens: Papazisi (in Greek).

Papadopoulos, T., \& Roumpakis, A. (2012). The Greek Welfare State in the Age of Austerity: Anti-social Policy and the Politico Economic Crisis. In Kilkey, M., Ramia, G. and Farnsworth, K. (eds). Social Policy Review, 24, 203-227. The Policy Press. https://doi.org/10.1332/policypress/9781447304470.003.0011

Papadopoulos, T., \& Roumpakis, A. (2013). Familistic Welfare Capitalism in Crisis: Social Reproduction and AntiSocial Policy in Greece. Journal of International and Comparative Social Policy, 29, 204-224. https://doi.org/10.1080/21699763.2013.863736

Petmesidou, M. (1991). Statism, Social Policy and the Middle Classes in Greece. Journal of European Social Policy, 1, 31-48.

Petmesidou, M. (1996). Social Protection in Southern Europe: Trends and Prospects. Journal of Contemporary European Studies, 4, 95-125.

Petmesidou, M. (2006). Tracking Social Protection: Origins, Path Peculiarity, Impasses and Prospects. In Petmesidou, M. and Mosialos, E. (Eded): Social Policy Developments in Greece. Hampshire: Ashgate Publishing.

Petmesidou, M. (2010). Pensions, Health and Long-term Care-Greece. Annual National Report Asisp (2010). Retrieved from http://socialprotection.eu/files_db/891/asisp_ANR10_Greece.pdf

Petmesidou, M. (2011). Pensions, Health and Long-term Care. Annual National Report-Greece Asisp (2011). Retrieved from http://socialprotection.eu/files_db/1109/asisp_ANR11_Greece.pdf

Petmesidou, M. (2012). Pensions, Health and Long-term Care. Annual National Report-Greece Asisp (2012). Retrieved from http://socialprotection.eu/files_db/1224/asisp_ANR12_Greece.pdf

Petmesidou, M. (2013a). Destructive Austerity and the Specter of "Immiseration" in the EU Periphery. To be published in the CROP Briefs Series.

Petmesidou, M. (2013b). Is Social Protection in Greece at a Crossroads? Journal of European Societies, Vol. 15.

Petmesidou, M. (2014). Pensions, Health and Long-term Care. Annual National Report-Greece Asisp (2014). Retrieved from http://socialprotection.eu/files_db/1224/asisp_ANR12_Greece.pdf

Petmesidou, M. And Guillen, A. (2014). Can the Welfare State as we Know it Survive? A View from the CrisisRidden South European Periphery. South European Society and Politics, 19, 295-307. https://doi.org/10.1080/13608746.2014.950369

Robolis, S. (2013). Economic Crisis and Welfare State. Social Policy (in Greek). https://doi.org/10.12681/sp.10543

Sotiropoulos, D., \& Bourikos, D. (2014). Economic Crisis, Social Solidarity and the Voluntary Sector in Greece. Journal of Power, Politics and Governance, 2, 33-53. Available online:http://jppgnet.com/journals/jppg/Vol_2_No_2_June_2014/3.pdf Theodorikakou, O., Alamanou, A., Katsadoros, K. (2013). Neo-homelessness and the Greek crisis. European Journal of Homelessness, 7. Retrieved from http://www.feantsa.org/download/ot_et_al_review6144018687950662512.pdf

Tinios, P. (2005). Pension Reform in Greece. "Reform by Instalments". A Blocked Process? West European Politics, $28,403-420$.

Tinios, P. (2010). A Method of Understanding the Social Security System. Athens: Critique Publications (in Greek).

Venieris, D. (2013). Crisis Social Policy and Social Justice: The Case for Greece. Hellenic Observatory Papers on Greece and the Southeast Europe, GreeSE Paper Nr.69. Retrieved from http://eprints.lse.ac.uk/50258/1/GreeSE_No69.pdf 


\section{Copyrights}

Copyright for this article is retained by the author(s), with first publication rights granted to the journal.

This is an open-access article distributed under the terms and conditions of the Creative Commons Attribution license (http://creativecommons.org/licenses/by/4.0/). 